7. Reprod. Fert. (1975) 44, 313-315

\title{
THE ONSET OF OESTRUS AND OVULATION IN LACTATING RATS
}

\author{
RHODA MANEGKJEE AND N. R. MOUDGAL \\ Laboratory of Endocrine Biochemistry, Department of Biochemistry, \\ Indian Institute of Science, Bangalore-560012, India
}

(Received 2nd Fanuary 1975)

Lactation delays the re-initiation of oestrous cyclicity in rats, resulting in physiological sterility for the duration of suckling. During this phase, the secretion of pituitary gonadotrophins is suppressed by an unknown mechanism. Continued application of the suckling stimulus by litter replacement (Bruce, 1958; Nicoll \& Meites, 1959), or injections of prolactin (Meites \& Nicoll, 1959), have been shown to prolong lactation considerably beyond the usual period.

The present study aimed to demonstrate the role of prolactin in inhibiting the gonadotrophin secretion necessary for the re-establishment of oestrous cyclicity during lactation.

Pregnant rats weighing approximately $300 \mathrm{~g}$ were obtained from the Institute colony and housed in individual cages. At parturition, the number of young in the litter was adjusted to eight, two or one as required. The day following the post-partum oestrus was regarded as Day 1 of lactation. The onset of oestrus was confirmed by the presence of cornified epithelial cells in the vaginal smear, and ovulation by the presence of ova in the oviducts at 10.00 hours on the day of oestrus.

Oestrus and ovulation occur on Day 22 of lactation in rats suckling eight young each and on Day 16 in those suckling either two or one young each. The data presented in Table 1 show that withdrawal of the young on Days 10 or 14 resulted in the appearance of oestrus and ovulation 2 days later. Increasing the number of young from two to eight on Day 15 caused a significant postponement of oestrus and ovulation, but reduction of the size of the litter to two again on Day 16 resulted in postponing oestrus and ovulation only by 1 day. Thus, it is clear that the greater the intensity of suckling, the longer is the duration of sterility.

Intensity of the suckling stimulus can be directly correlated with an increase in prolactin levels and therefore the effect of giving prolactin to lactating rats on the recurrence of oestrus was studied. Administration of $100 \mu \mathrm{g}$ prolactin (ovine prolactin, NIH-P-S9) as a single subcutaneous injection on Day 14 to rats suckling two young each led to a significant delay (from Day 16 to Day 21) in the onset of oestrus and ovulation (Table 2). Injections of prolactin from Days 14 to 16 resulted in a further delay in the re-establishment of cyclicity. A single prolactin injection on Day 20 to lactating rats suckling eight young each postponed oestrus and ovulation from the normal Day 22 to Day 27. 
Table 1. Effect of litter size on the onset of oestrus and ovulation in lactating rats

\begin{tabular}{|c|c|c|c|c|}
\hline Group & $\begin{array}{l}\text { No. of } \\
\text { rats }\end{array}$ & $\begin{array}{l}\text { No. of } \\
\text { young }\end{array}$ & $\begin{array}{l}\text { Day of oestrus* } \\
\text { (Mean } \pm \text { S.D. }\end{array}$ & Significance \\
\hline I & 6 & 8 & $22 \pm 0$ & \\
\hline II & 10 & 2 & $16 \pm 2$ & $P<0.001(\mathrm{I}: \mathrm{II})$ \\
\hline III & 5 & 1 & $16 \pm 1$ & $P<0.001(\mathrm{I}: \mathrm{III})$ \\
\hline IV & 5 & $2 \rightarrow 0$ on Day 10 & $12 \pm 0$ & \\
\hline V & 4 & $2 \rightarrow 0$ on Day 14 & $16 \pm 0$ & \\
\hline VI & 5 & $2 \rightarrow 8$ on Day 15 & $25 \pm 1$ & $P<0.001(\mathrm{II}: \mathrm{VI})$ \\
\hline VII & 5 & $\begin{array}{l}2 \rightarrow 8 \text { on Day } 15, \\
\text { reduced to } 2 \\
\text { again on Day } 16\end{array}$ & $18 \pm 0$ & \\
\hline
\end{tabular}

Horizontal arrows indicate the adjustment in litter size on the appropriate day.

* And ovulation which was checked by examination of the oviducts for the presence of ova.

Table 2. Effect of prolactin and progesterone on the onset of oestrus and ovulation in lactating rats

\begin{tabular}{ccccccc}
\hline & & & \multicolumn{2}{c}{ Day of treatment } & Day of oestrus & Significance \\
\cline { 5 - 7 } & $\begin{array}{c}\text { No. of } \\
\text { rats }\end{array}$ & $\begin{array}{c}\text { No. of } \\
\text { Day 14 }\end{array}$ & $(100 \mu g /$ day $)$ & $(50 \mu g /$ day $)$ & & \\
\hline I & 10 & 2 & - & - & $16 \pm 2 \cdot 0$ & \\
II & 6 & 8 & - & - & $22 \pm 0 \cdot 0$ & $P<0.001$ (I:II) \\
III & 5 & 2 & 14 & - & $21 \pm 1.5$ & $P<0.001$ (I:III) \\
IV & 6 & 2 & $14,15,16$ & - & $24 \pm 1 \cdot 0$ & $P<0.001$ (I:IV) \\
V & 5 & $2 \rightarrow 0^{*}$ & $14,15,16$ & - & $18 \pm 1 \cdot 0$ & $0.05<P<0 \cdot 1$ (I:V) \\
VI & 6 & 8 & 20 & - & $27 \pm 1.4$ & $P<0.001$ (II:VI) \\
VII & 5 & 2 & - & $14,15,16$ & $21 \pm 0.0$ & $P<0.001$ (I:VII) \\
VIII & 5 & $2 \rightarrow 0^{*}$ & - & $14,15,16$ & $21 \pm 0.0$ & $P<0.001$ (I:VIII) \\
\hline
\end{tabular}

* Reduction of young from two to none on Day 14.

By contrast, if lactating rats were deprived of their litters on Day 14 and prolactin was administered on that day alone or from Days 14 to 16 , no delay could be observed in the onset of oestrus and ovulation. These results demonstrate that suckling has a facilitatory or permissive effect on prolactin action. A similar permissive effect of suckling on the ability of prolactin to block implantation in rats suckling two young each has been observed (Maneckjee \& Moudgal, 1975).

Thus, the onset of oestrus and ovulation in lactating rats only awaits the removal of the lactational block to gonadotrophin release. Following the introduction of a lactational stimulus, the inhibition is almost immediately effective. Although the lactational block is a combined effect of high prolactin levels and suckling, it is evident that the circulatory level of prolactin is the 
primary factor that determines the duration of the postponement of oestrous cyclicity.

The suppressive action of prolactin on gonadotrophin release may be explained on the basis of its ability to increase progesterone secretion which, in turn, is known to have a negative feedback effect on gonadotrophin secretion. When $50 \mu \mathrm{g}$ progesterone were injected subcutaneously daily at 10.00 hours from Days 14 to 16 of lactation, to rats suckling two young or fewer, the onset of oestrus and ovulation was delayed (Table 2). This suggests that progesterone is not a mediator of prolactin action. Preliminary results from our laboratory have indicated that administration of exogenous prolactin to rats suckling a minimum number of young results in a significant reduction in plasma LH levels within $8 \mathrm{hr}$. This effect was seen even in ovariectomized rats, suggesting that prolactin is acting directly on the hypothalamus or pituitary, inhibiting release of LH (K. Muralidhar, R. Maneckjee and N. R. Moudgal, unpublished data). Moreover, Ford \& Melampy (1973) reported that an increase in plasma levels of gonadotrophin occurred in intact and ovariectomized lactating rats after premature weaning, and Meites (1970) observed that there were significantly lower levels of LH and LH-releasing hormone in the pituitary and hypothalamus, respectively, in the lactating rat than in the non-lactating rat.

The authors express their thanks to the Indian Council of Medical Research, New Delhi, The Ford Foundation, New York, and the Council of Scientific and Industrial Research, New Delhi, for financial assistance. They are appreciative of the helpful suggestions made by Professor Harry Lipner in the preparation of the manuscript, and Mr P. Pasupathy for typing the manuscript.

\section{REFERENGES}

Bruce, H. (1958) Suckling stimulus and lactation. Proc. R. Soc. B, 149, 421-423.

FORD, J.J. \& MeLAMPY, R.M. (1973) Gonadotropin levels in lactating rats: effect of ovariectomy. Endocrinology 93, 540-547.

Mertes, J. (1970) Modification of synthesis and release of hypothalamic factor induced by exogenous stimuli. In Neurochemical Aspects of Hypothalic Function, pp. 1-43. Eds. L. Martini and J. Meites. Academic Press, New York.

Mertes, J. \& Nicoll, G.S. (1959) Hormonal prolongation of lactation for 75 days after litter withdrawal in post-partum rats. Endocrinology 65, 572-579.

Nicoll, G.S. \& Meites, J. (1959) Prolongation of lactation in the rat by litter replacement. Proc. Soc. exp. Biol. Med. 101, 81-82.

Maneckjee, R. \& Moudgal, N.R. (1975) Induction and inhibition of implantation in lactating rats. 7. Reprod. Fert. 43, 33-40. 